\title{
Multi-material NiTi-PEEK hybrid cellular structures by Selective Laser Melting and Hot Pressing: Tribological characterization
}

\author{
M.M. Costa ${ }^{\text {a, }}$, F. Bartolomeu ${ }^{\text {a }}$, J. Palmeiro ${ }^{\text {a }}$, B. Guimarães ${ }^{a}$, N. Alves ${ }^{\text {b }}$, G. Miranda $^{\text {a,c }}$, F. \\ S. Silva ${ }^{\text {a }}$ \\ ${ }^{\text {a }}$ Center for MicroElectroMechanical Systems (CMEMS-UMinho), University of Minho, Campus de Azurém, 4800-058, Guimarães, Portugal \\ ${ }^{\mathrm{b}}$ Centre for Rapid and Sustainable Product Development Polytechnic Institute of Leiria, Rua General Norton de Matos, Apartado 4133, 2411-901, Leiria, Portugal \\ ${ }^{\mathrm{c}}$ CICECO, Aveiro Institute of Materials, Department of Materials and Ceramic Engineering, University of Aveiro, 3810-193, Aveiro, Portugal
}

\section{A R T I C L E I N F O}

\section{Keywords:}

Multi-material structures

NiTi-PEEK

Selective laser melting

Hot pressing

\begin{abstract}
A B S T R A C T
In this study, a multi-material NiTi-PEEK cellular structured solution was designed, produced and characterized targeting orthopedic applications. For that purpose, Selective Laser Melting (SLM) technique was used to produce NiTi cellular structures with different open-cell sizes and wall thicknesses. Hot Pressing (HP) technique was used to introduce PEEK in the open-cells of NiTi structures to obtain multi-material components. Morphological characterization showed that the selected SLM processing parameters were suited to achieve high-quality parts without significant defects. Tribological characterization proved an enhanced wear resistance to the multimaterial specimens when compared with the mono-material NiTi structures. These multi-material structures are a promising solution for providing a customized stiffness and superior wear resistance to NiTi structures to be integrated in innovative orthopedic designs.
\end{abstract}

\section{Introduction}

The selection of a biomaterial for fabricating an implant is of utmost importance for its success, once it should be able to (i) allow bone regeneration not being harmful to the host, thus, displaying high biocompatibility; (ii) have suitable mechanical properties, by displaying adequate stiffness and strength, high corrosion and wear resistance [1-5].

Metals, such as Ti6Al4V, have been historically used as orthopedic implant materials, once they meet satisfactorily with some of these requirements in terms of mechanical strength, high corrosion resistance and biocompatibility [1,5-8]. However, improvements are still needed to enhance their overall performance once implant loosening often occurs, consequently leading to revision surgeries [4,9-11]. The high elastic modulus and poor wear resistance of Ti6Al4V, besides a non-uniform contact between implant and bone are the three main factors accountable for implants failure [7,9,10].

Nickel-Titanium (NiTi) shape memory alloy owes attractive properties for biomedical applications of different areas like cardiology (e.g. stents), neurology and orthodontics $[1,3,12,13]$. NiTi shape memory effect (SME) and superelasticity (SE) together with its high strength, fatigue wear and corrosion resistance, and high biocompatibility [13-16] make this alloy also a good candidate for orthopaedic implants $[4,17]$. Compared with Ti6Al4V, besides the addition of SME and SE, NiTi displays higher wear resistance and lower elastic modulus [13].

The control of an implant porosity allows to tailor its elastic modulus, desirably to values closest to that of bone in order to avoid the stress-shielding effect $[4,12,18,19]$. NiTi elastic modulus $(\approx 40-75 \mathrm{GPa}$ $[13])$ is still high when compared to that of bone $(\approx 10-30 \mathrm{GPa}[2,13])$, thus the creation of engineered porous NiTi structures can allow to lower this value. Additionally, in an open-cell structured implant, the porosity will allow nutrient flow and vascularization for osteoblasts and mesenchymal cells to adhere and proliferate and, consequently, for bone to growth into the implant pores and create a strong implant-bone bond [4, $12,18,19]$. In literature, the adequate pore or open-cell size to promote bone ingrowth ranges between 100 and $600 \mu \mathrm{m}[4,12]$. Finally, another advantage of NiTi as implant material is its shape memory effect, that can be used to promote an implant expansion once implanted, promoting an uniform contact pressure within the bone, increasing implant fixation [18].

Machining and processing NiTi presents some challenges due to its high ductility, adhesion, work hardening and reactivity to titanium

\footnotetext{
* Corresponding author.

E-mail address: amafmcosta@gmail.com (M.M. Costa).
} 
Table 1

Selective Laser Melting parameters used for NiTi cellular structures production.

\begin{tabular}{lllll}
\hline Laser Power & Scan Speed & Scan Spacing & Layer Thickness & Energy Density \\
\hline $90 \mathrm{~W}$ & $600 \mathrm{~mm} / \mathrm{s}$ & $90 \mu \mathrm{m}$ & $30 \mu \mathrm{m}$ & $55.6 \mathrm{~J} / \mathrm{mm}^{3}$ \\
\hline
\end{tabular}

(A)

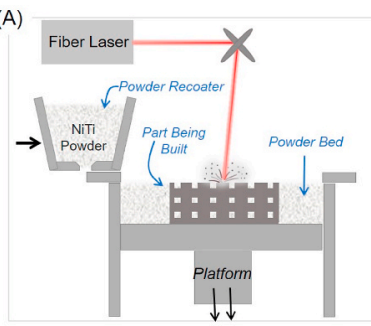

(B)
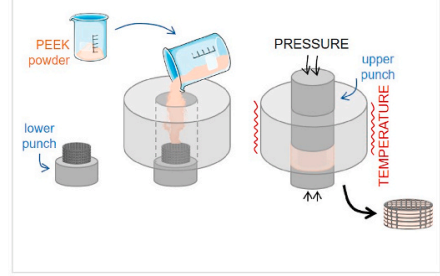

Fig. 1. Schematic representation of (A) SLM building and (B) PEEK impregnation processes.

content [14-16,20-22]. Furthermore, conventional manufacturing technologies limit the fabrication of complex NiTi parts. Recently, the emergence of Additive Manufacturing (AM) technologies allow to overcome some of these conventional technologies issues and produce complex parts, layer by layer, directly from CAD data [17,19]. Among AM techniques, Selective Laser Melting (SLM) is commonly used for the production of NiTi complex parts [16,20,21,23]. Specially regarding orthopedic applications, this technique makes possible to manufacture customized implants for a specific patient anatomy [20].

Poly-ether-ether ketone (PEEK) is a biocompatible polymer, extremely attractive for the medical field, especially for orthopedic implants, due to its high chemical stability, excellent wear and corrosion resistance [4,24-26]. PEEK elastic modulus ( $\approx 3.6 \mathrm{GPa}[27,28])$ is much lower than that of bone and despite its advantageous properties, its mechanical strength is inadequate for load-bearing applications as orthopedic implants [25,27]. The combination of PEEK and NiTi in an engineered structure allows tackling this last problem.

In physiological conditions, micromovements at the implant-bone interface occur and may result in metallic debris release to the interface, which was already found in literature that, besides promoting bone resorption, can cause allergic and toxic reactions to the tissue [29-31]. Literature on the improvement of Ti6Al4V poor wear resistance is quite vast, by applying coatings, creating multi-material solutions and so on $[6,10,32]$, however, besides being promising solutions, NiTi high wear resistance allied with its unique properties make it an outstanding biomaterial implant substitute. It is already reported in literature that, contrary to conventional materials, NiTi wear performance is not only dependent on its mechanical properties (e.g. hardness, work-hardening, etc), but also its superelastic effect [33-35]. In this sense, the tribological response of NiTi cellular structures should be investigated to assess its applicability in implant solutions. It is important to highlight that, to the authors best knowledge, the present study is the pioneer regarding tribological characterization of NiTi cellular structures by SLM technique.

In this study, mono-material NiTi cellular structures were produced by SLM and multi-material NiTi-PEEK structures were obtained by SLM and HP for PEEK impregnation, being tribologically characterized.

\section{Experimental details}

\subsection{Specimens fabrication}

NiTi cellular structures were designed and manufactured by SLM using an equipment from SLM solutions (model 125HL) equipped with a $400 \mathrm{~W}$ Ytterbium-fiber laser. For that purpose, a $\mathrm{Ni}_{50.8} \mathrm{Ti}_{49.2}$ (at. \%) ingot (SAES Smart Materials, USA) was atomized at TLS technique GmbH (Germany) through an electrode induction melting gas atomization (EIGA) technique. The NiTi powder with spherical morphology, displaying a particle size diameter (D50) of $47.5 \mu \mathrm{m}$. Multi-material NiTiPEEK structures were fabricated using PEEK powder, obtained from Evonik Industries (Germany), which presents an irregular shape and a particle size (D50) of $50 \mu \mathrm{m}$.

Table 1 displays the processing parameters used to produce NiTi cellular structures, that were selected based on previous optimization studies [36,37].

Briefly, SLM process starts with the design of the structures using a CAD software, being the file then imported to a SLM equipment that will produce the part, layer by layer, by melting, via laser, the powder bed in specific sites (Fig. 1(A)). SLM process was conducted under argon atmosphere using a Ti6Al4V platform at $200{ }^{\circ} \mathrm{C}$.

The specimens produced in this study displayed an average height and diameter of approximately $2.66 \pm 0.34 \mathrm{~mm}$ and $6.08 \pm 0.04 \mathrm{~mm}$, respectively. The architecture of these specimens consists in a cubic-like structure with interconnecting porosity that differs in terms of open-cell sizes $(500$ or $600 \mu \mathrm{m})$ and wall thicknesses $(100,150$ and $350 \mu \mathrm{m})$. After the SLM production, these cellular structures were impregnated with PEEK by means of a pressure-assisted technique, Hot Pressing (HP). In this technique, pressure and temperature are applied, simultaneously, to melt the polymer and force it to fill the open-cells of the NiTi structure, thus creating a multi-material NiTi-PEEK structure. The impregnation process, depicted in Fig. 1(B), starts with the placement of the NiTi specimens on top of the lower punch, followed by the positioning of the die and PEEK powder insertion. With the positioning of the upper punch, the system is placed inside a chamber under vacuum atmosphere $\left(10^{2}\right.$ mbar). Firstly, to accommodate the powder, a residual pressure is applied before beginning the thermal cycle. Afterwards, the system is heated using an induction coil until the temperature reaches $380{ }^{\circ} \mathrm{C}$, above PEEK melting point $\left(345^{\circ} \mathrm{C}\right)$. Then the temperature is decreased until $300^{\circ} \mathrm{C}$ and, to force PEEK to fill the open cells, a small pressure of approximately $10 \mathrm{MPa}$ was applied and kept for $5 \mathrm{~s}$. This cycle was repeated two times and then the sample was allowed to cool inside the chamber till room temperature.

Table 2

CAD model design and SLM.Produced details (P denoting specimens with PEEK).

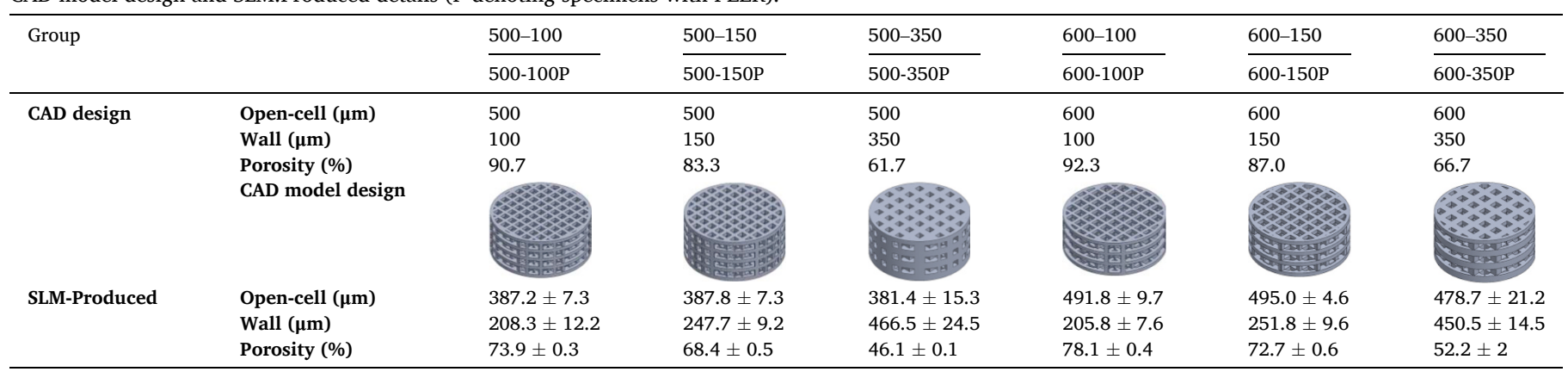




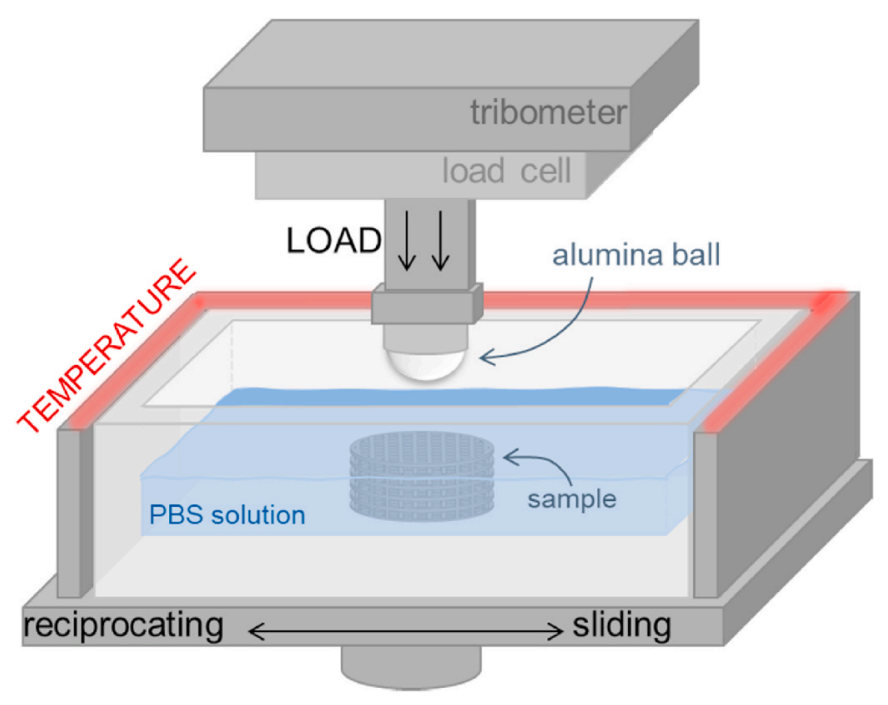

Fig. 2. Schematic illustration of the tribological apparatus.

Following these fabrication strategies (SLM and SLM + HP), a total of twelve groups were manufactured for the present study, where six of them are NiTi cellular structures and the other six NiTi-PEEK multimaterial cellular structures. Table 2 resumes the main features of these groups of specimens, namely, CAD model design and open-cell, wall sizes and porosity of CAD design and SLM-produced specimens. Porosity was determined for all specimens by determining their mass and volume and considering the theoretical density of NiTi.

\subsection{Tribological tests}

After fabrication, NiTi cellular structures were prepared for tribological testing by polishing down to 4000 mesh by using SiC abrasive paper and subsequent ultrasonic cleaning for $5 \mathrm{~min}$ in isopropanol. Afterwards, the specimens were placed inside an acrylic device fixed to a tribometer (Bruker-UMT-2, USA), where ball-on-plate reciprocating sliding tests were performed using a $10 \mathrm{~mm}$ alumina $\left(\mathrm{Al}_{2} \mathrm{O}_{3}\right)$ ball, from Ceratec, $N L$, as counterpart and the specimens as plates. Fig. 2 shows a schematic representation of the tribological tests carried out in the present study. The tests were conducted with the specimens immersed in phosphate buffered solution (PBS) at $37 \pm 2{ }^{\circ} \mathrm{C}$, under a $6 \mathrm{~N}$ normal load, at a frequency of $1 \mathrm{~Hz}$, for $30 \mathrm{~min}$. For each group, an average ranging from 3 to 6 repetitions were performed, being the results presented as the average \pm standard deviation. The values for the coefficient of friction (COF) were obtained directly from the tribometer and the results were determined by the average of the COF values, when the steady state regime of each specimen was achieved.

After the tribological tests, the specimens were cleaned in isopropanol to remove loose wear debris and an optical microscope from Leica Microsystems (Leica DM 2500, Germany) was used for wear track observation. The width and length of the wear tracks were measured using Image $J$ software, to further calculate the total volume loss. Since NiTi cellular structures are not dense, it was necessary to develop a methodology for estimating the volume loss, taking into consideration the empty spaces of the wear track. The methodology adopted for volume loss determination using a CAD software will be thoroughly described as follows:

Firstly, it is important to highlight that adjusted CAD designs were modeled for each group by substituting the designed dimensions by the real dimensions (open-cell and thickness) that were measured after SLM fabrication. More details on these differences between CAD design and SLM fabricated parts can be found in literature [38-42]. From the "adjusted CAD model" of each group, the initial volume of the specimen was taken from the software and, subsequently, the wear track that was previously designed in 3D (considering the collected width and length of the track) was imported. Then, optical microscope images of each specimen track were imported and properly positioned and rescaled taking into account the known measurements. Finally, the 3D wear track was matched together with the image and subtracted from the final specimen, to determine its final volume, without the track. The total volume loss was, then calculated, by the difference between the initial and final volume of the specimen. For NiTi-PEEK multi-material structures, it was not necessary to apply such strategy since the holes are now filled with PEEK. In this regard, the total volume loss was obtained by drawing the 3D wear track using the width and length measurements, assuming that these tracks result of the sliding of a perfect alumina ball geometry.

With all volume losses calculated for the twelve groups, the specific wear rate was determined according to Archard's model, as follows:

$k=\frac{\Delta V}{F \times S}$

where $\mathrm{k}$ is the specific wear rate $\left(\mathrm{mm}^{3} / \mathrm{Nm}\right), \Delta V$ the total volume loss of the wear track $\left(\mathrm{mm}^{3}\right), F$ the normal applied load $(\mathrm{N})$ and $S$ the total sliding distance $(\mathrm{m})$.
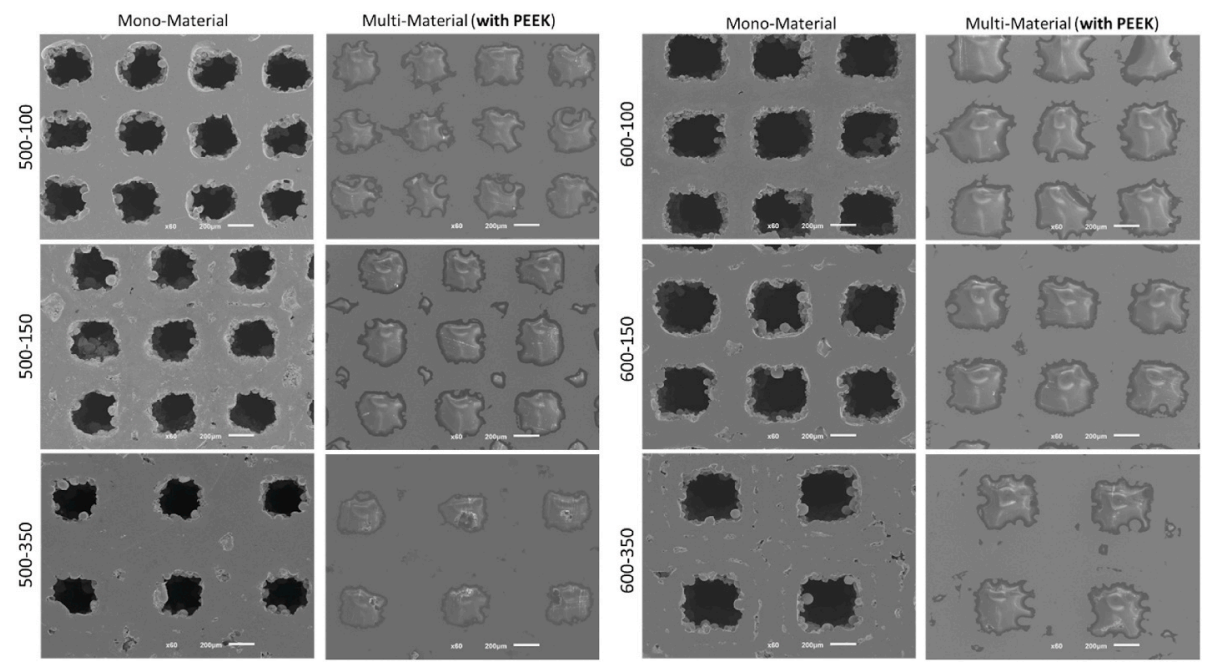

Fig. 3. SEM micrographs of the NiTi cellular structures produced by SLM. 

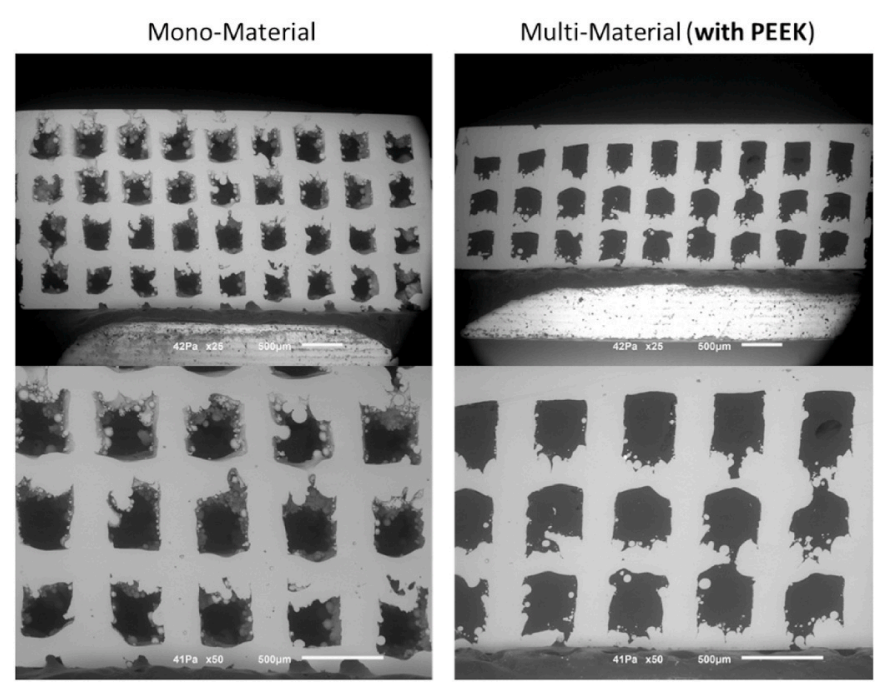

Fig. 4. Cross-section view of SEM micrographs of 500-100 mono-material and multi-material specimens.

\subsection{Scanning Electron Microscopy (SEM) and X-ray diffraction (XRD) analysis}

Surface morphology and microstructure of the specimens from the different groups, before and after tribological tests, were analyzed by Scanning Electron Microscopy (SEM). Additionally, after SLM fabrication and PEEK impregnation, X-ray diffraction analysis (XRD) was also performed, being the data collected in a Bruker AXS D8 Discover (USA) equipment from 10 to $90^{\circ}$, with a step size and counting time of $0.02^{\circ}$ and $1 \mathrm{~s}$, respectively. Finally, after the tribological tests, Energydispersive X-Ray spectroscopy analysis (EDS) was used in some specific sites of the specimens for chemical characterization, being the alumina ball observed by SEM and EDS to assess eventual material transfer.

\section{Results and discussion}

\subsection{Morphological, crystallographic and mechanical characterization}

In the present study, NiTi mono-material and NiTi-PEEK multi-material cellular structures with different open-cell sizes and wall thicknesses were developed and studied. Fig. 3 resumes top views SEM micrographs of all twelve different structures produced.

Few studies in literature report high-quality SLM-produced NiTi cellular structures. This study was able to, by using adequate materials and processing parameters to produce such structures successfully.

By analyzing mono-material cellular structures some deviations between the real dimensions obtained for open-cell sizes and wall thicknesses and the ones designed in the CAD model are observed, with these structures displaying lower open-cell sizes and higher wall thicknesses. This phenomenon, already reported in literature, is typical of SLM process and is related with powder related aspects and partial melting of powder particles near the laser melted zones [6,39,41,43,44].

To the author's best knowledge, this study is the first reporting a multi-material component gathering NiTi and PEEK within a cubic-like cellular architecture. By observing the multi-material specimens, it can be concluded that the impregnation of PEEK into the open cells was successfully achieved, with an effective mechanical interlocking. Fig. 4 displays the cross-section view of mono- and multi-material 500-100 specimens as an example of the microstructure found for the produced specimens. By analyzing these SEM micrographs it is possible to observe that, in one hand, SLM technique allowed to produce high-quality NiTi cellular structures with good densification and, on the other hand, the

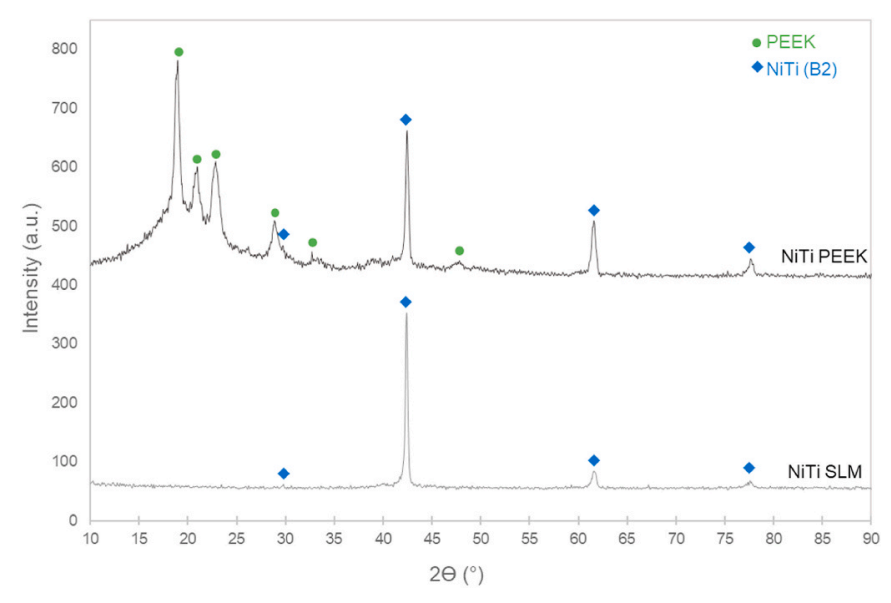

Fig. 5. X-ray diffraction patterns of NiTi-SLM specimens before and after PEEK impregnation.

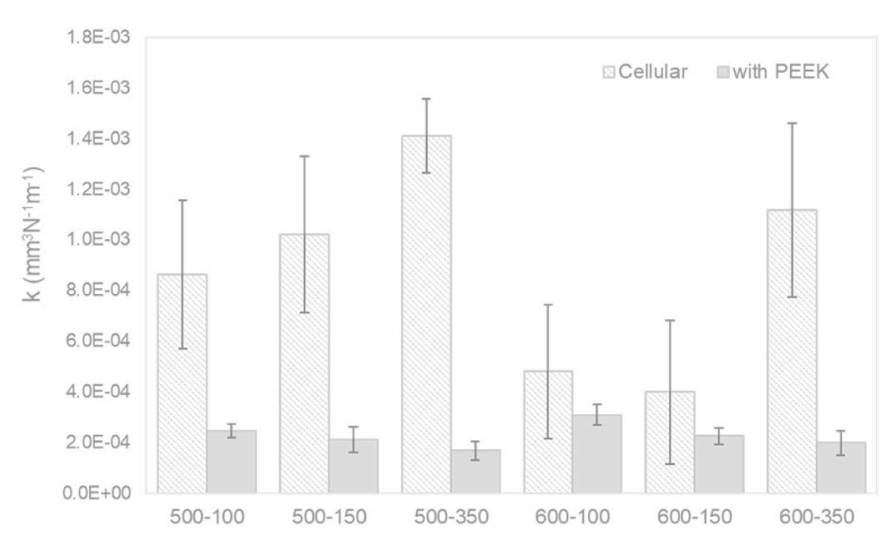

Fig. 6. Specific wear rate for all the tested specimens, against alumina ball.

adopted strategy to impregnate PEEK into the cellular structures was successfully validated, once an effective impregnation with mechanical interlocking is observed inside the produced specimens.

To determine the existing phases in the mono- and multi-material specimens, XRD analyses were performed and the resulting spectra are shown in Fig. 5. Both spectra evidence the main peaks matching to the austenite phase (cubic B2 phase) of NiTi that, according to reference pattern number $03-065-5746$, present major peaks at $42.436^{\circ}, 77.637^{\circ}$ and $61.571^{\circ}$. NiTi martensitic phase (B19' monoclinic) has four main peaks at $41.365^{\circ}, 44.927^{\circ}, 39.223^{\circ}$ and $43.917^{\circ}$ (reference pattern

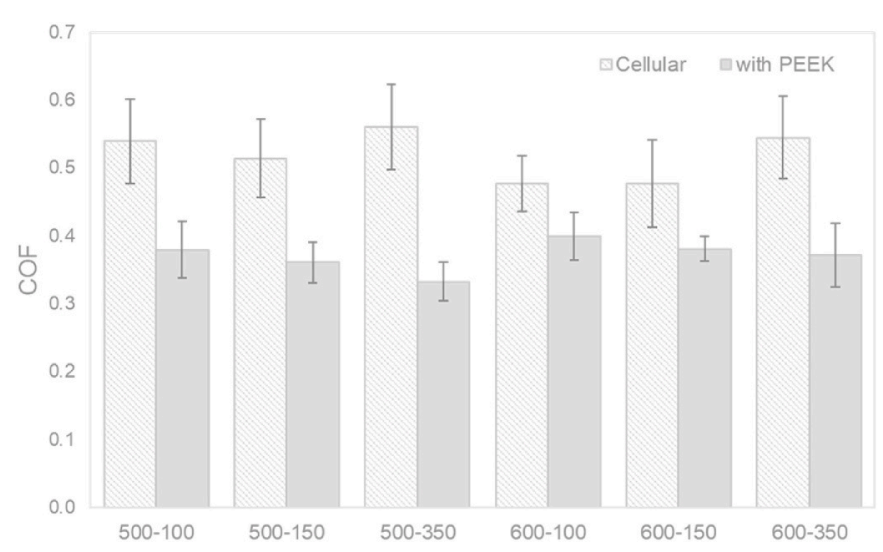

Fig. 7. Average coefficient of friction for all the tested specimens, against alumina ball. 

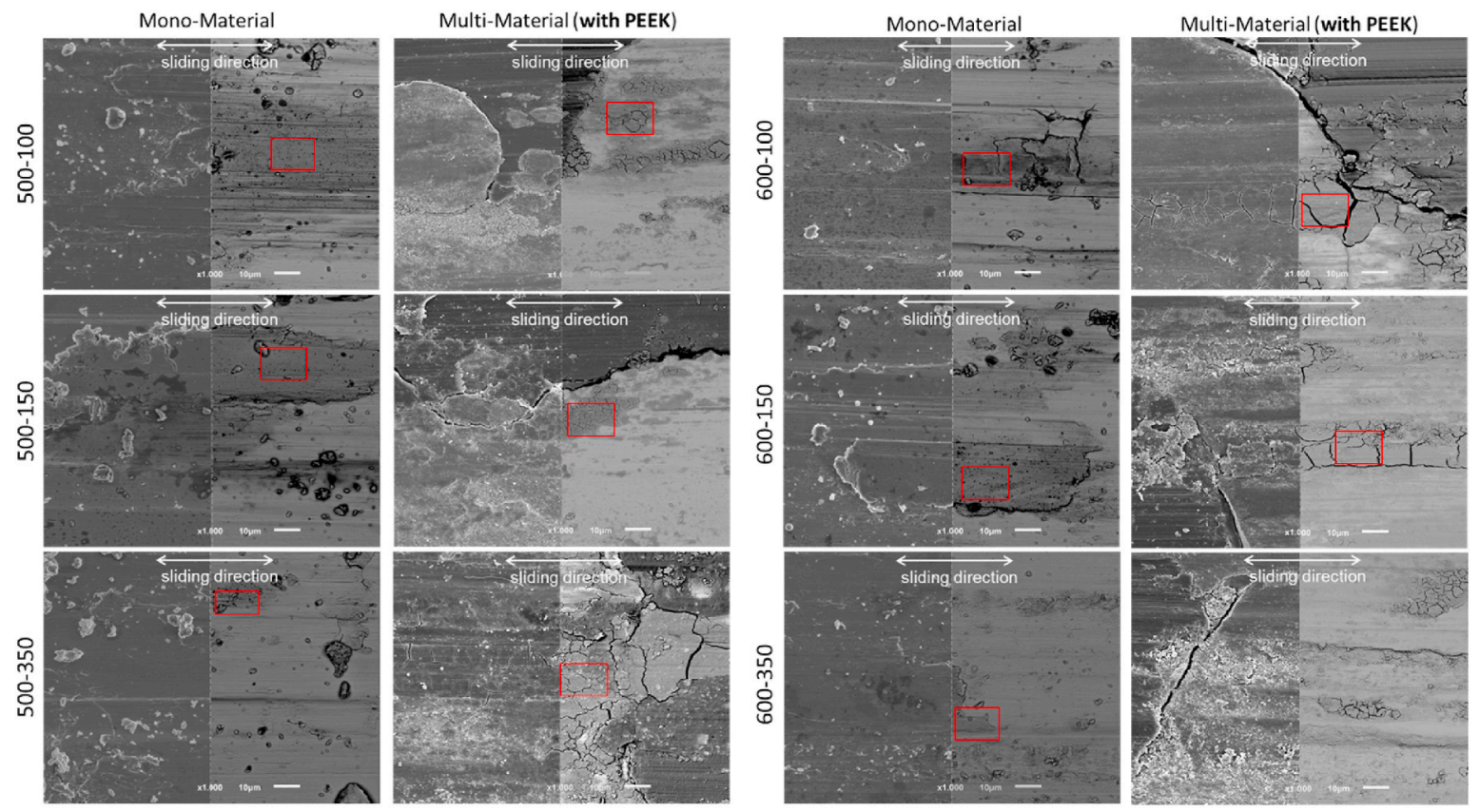

Fig. 8. SEM micrographs of the worn NiTi cellular structure specimens against $\mathrm{Al}_{3} \mathrm{O}_{2}$ ball.

number 00-035-1281). And although the XRD spectrum for the multimaterial (Fig. 5) show no clear indication of these peaks, that may be undetectable, a work by Saedi et al. [45] show that changes in transformation temperatures of NiTi specimens are observed after thermal treatments performed from as low as $350{ }^{\circ} \mathrm{C}$, when compared to as produced parts by SLM. No other Ni-Ti intermetallic phases are detected in these spectra. Finally, several additional peaks were detected in the multi-material XRD spectrum, attributable to PEEK, in agreement with some PEEK patterns found in literature [7,27].

\subsection{Tribological analysis}

The tribological results regarding specific wear rate and coefficient of friction (COF) are shown Figs. 6 and 7, respectively.

It is important to highlight that, in conventional materials, wear resistance highly depend on their mechanical properties such as hardness, strength, toughness, ductility, work hardening and crystallographic texture [34,35,46,47]. However, in shape memory alloys, like $\mathrm{NiTi}$, these properties are insufficient to comprehend their tribological behavior. Many studies in literature reported that the high wear resistance of NiTi alloy is also attributed to its superelastic behavior, which means that it also depends of the stress-induced martensitic transformation and reorientation of martensitic phase under stress [33,35,46, 48]. In one hand, the reorientation of martensite phase may hinder crack propagation, once it can accommodate the deformation strain and, on the other hand, superelastic behavior decreases the sliding stress by increasing the elastic contact area $[34,46,48,49]$.

The wear testing conditions is another factor that influences NiTi wear performance once the superelastic behavior may be compromised. It is clear that, for all materials, the testing conditions influence wear resistance, however, in NiTi, during wear tests, the load and thermal cycles may lead to microstructural changes that will influence wear performance and superelasticity [35].

In the present study, under the defined tribology conditions ( $6 \mathrm{~N}, 1$ $\mathrm{Hz}$ and $37^{\circ} \mathrm{C}$ ), superelasticity may be a factor influencing wear resistance. Some authors report that under high loads the superelastic property is not completely functional and deformation started to occur, contrary to what happens when tested at lower loads [34,35]. Neupane et al. [35] studied the superelastic behavior of NiTi under reciprocating sliding contact with different loads and frequencies. At lower frequencies and normal loads, the main factor influencing wear is the hardening of NiTi and stress-induced austenite to martensite with temperature.

Results show that the introduction of PEEK in these metallic structures led to an increase in their wear resistance, once significantly lower specific wear rates were observed for the multi-material solution (when PEEK is present) when compared to the corresponding unreinforced structures (see Fig. 6). This reduction was similar for all groups: $72 \%$ decrease for $500-100$ group, $79 \%$ for $500-150$, $88 \%$ for $500-350,36 \%$ for $600-100,43 \%$ for $600-150$ and $600-350$, leading to an overall average decrease of $82 \%$. This outcome is attributed to PEEK selflubrication ability, high heat resistance, low coefficient of friction, excellent wear and corrosion resistance and favorable mechanical strength [4,24-26].

In respect to the COF results (Fig. 7), a similar tendency is observed as the average COF values obtained for all the multi-material NiTi-PEEK cellular structures are lower than those for the mono-material NiTi structures. Literature reports a COF value around 0.1 for bulk PEEK against alumina [28]. Consequently, it would be expected that the overall COF of the multi-material specimens lowers. In fact, an average decrease of $30 \%$ was observed for $500-100$ and $500-150$ groups, $41 \%$ for $500-350,16 \%$ for $600-100,20 \%$ for $600-150$ and $32 \%$ for $600-350$ group, when considering the impregnation of PEEK. These results are aligned with some studies found in literature where the introduction of PEEK in Ti alloys metallic cellular structures lead to an increased wear resistance and lower values of coefficient of friction [26-28,32]. PEEK self-lubrication ability and superior wear resistance [28,32,50] can explain these results.

When analyzing the wear results of NiTi mono-material it can be observed that specimens with lower porosity (lower number of opencells on a given area) show a higher specific wear rate and thus a lower wear resistance. Theoretically, under the same wear conditions, higher porosity (more open-cells) would lead to higher specific wear rates due to a higher contact pressure. However, in the present work, this was not observed, indicating that for these NiTi architectures under these specific conditions, other phenomenon is controlling the tribological interaction. The fact that structures with higher open-cell sizes or more open-cells may be able to collect a superior amount of wear debris 

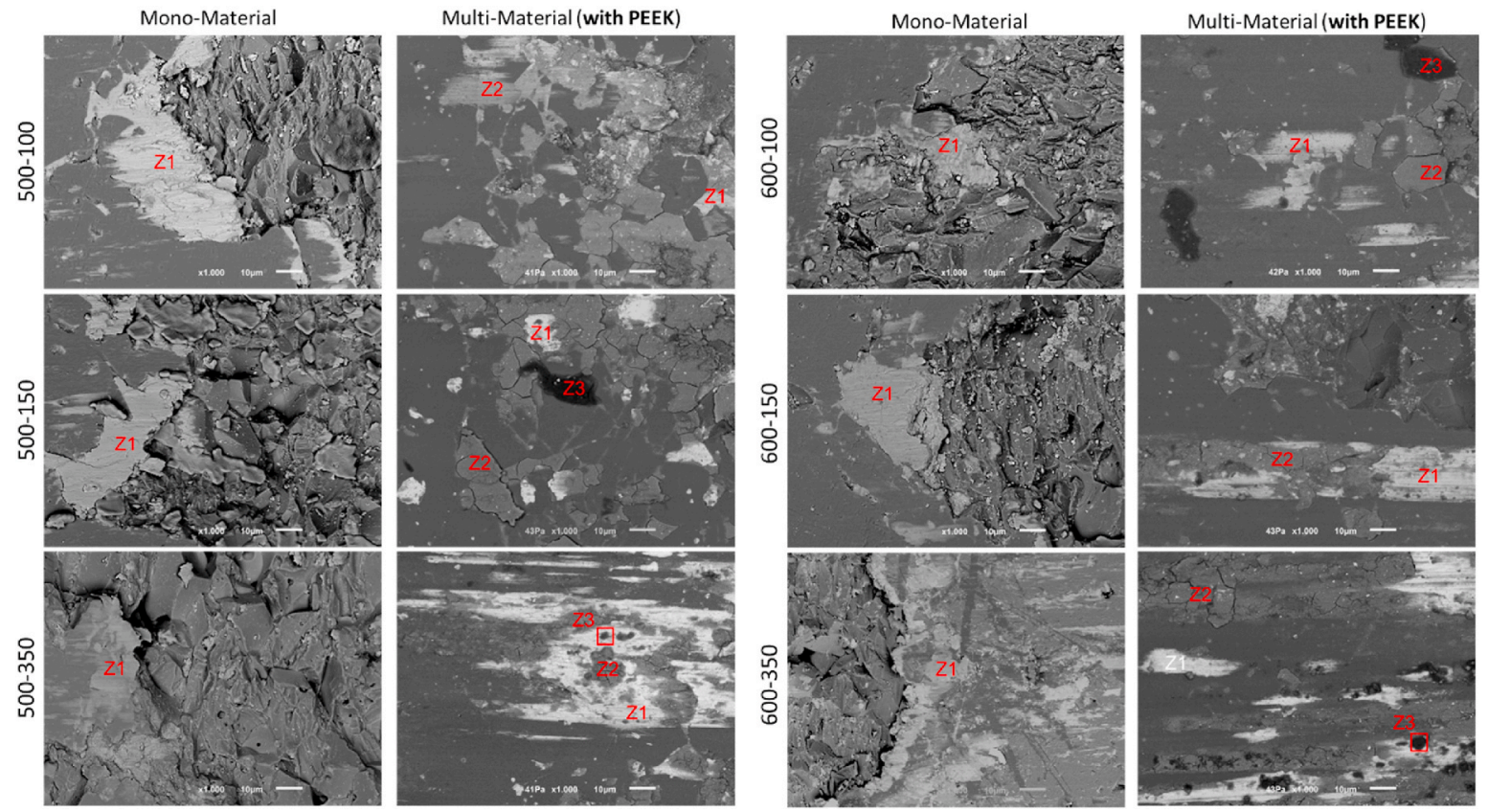

Fig. 9. SEM micrographs of the $\mathrm{Al}_{3} \mathrm{O}_{2}$ balls after wear tests against NiTi cellular structure specimens.

in these holes can explain these results, by reducing the third body wear mechanism in structures having higher porosity. By this mean, these work-hardened particles that severely contribute to abrasion wear are pushed out from the sliding area, thus reducing the overall wear on these structures.

The specific wear rate for NiTi mono-material structures ranges from $4.0 \times 10^{-4}$ to $1.4 \times 10^{-3} \mathrm{~mm}^{3} \mathrm{~N}^{-1} \mathrm{~m}^{-1}$, approximately. Stainless steel and Ti6Al4V titanium alloy are some materials used in the implantology field, being the later the most commonly used, as already mentioned. Bartolomeu et al. [51] reported a specific wear rate for stainless steel of, approximately, 3 to $5 \times 10^{-5} \mathrm{~mm}^{3} \mathrm{~N}^{-1} \mathrm{~m}^{-1}$ for Cast, Hot-Pressed and SLM dense specimens and, in another study [52], it was reported a specific wear rate for Ti6Al4V of around 6 to $8 \times 10^{-4} \mathrm{~mm}^{3} \mathrm{~N}^{-1} \mathrm{~m}^{-1}$ for Cast, Hot-Pressed and SLM dense specimens. When compared with these implant materials, the specific wear rate for the NiTi mono-materials structures present in this study is slightly higher than SS and similar than Ti6Al4V. Similarly, when searching in literature for the tribological behavior of NiTi specimens, the results are scarce. Nevertheless, Neupane et al. [35] reported an average specific wear rate of $7.5 \times$ $10^{-5} \mathrm{~mm}^{3} \mathrm{~N}^{-1} \mathrm{~m}^{-1}$. However, it is important to highlight that these values reported in literature are for dense structures, being the slightly higher value of the specific wear rate in this study explained by the presence of the open-cells. When compared with multi-material structures, this value decreases significantly, to values ranging from around 1.7 to $3.1 \times 10^{-4} \mathrm{~mm}^{3} \mathrm{~N}^{-1} \mathrm{~m}^{-1}$, which are higher than the ones reported in the Ti6Al4V study already mentioned and near to the ones reported for NiTi dense specimens, being these results explained by the addition of PEEK material to the structures, as already stated.

Fig. 8 shows SEM images of all the mono-material NiTi and multimaterial NiTi-PEEK structures after the tribological tests against alumina ball.

By analyzing this figure, it is possible to observe the damaged features of the tribological interaction related to the prevailing wear mechanisms. All the specimens displayed abrasive wear by exhibiting a series of grooves parallelly aligned with the sliding direction, scratch marks and some wear debris. These abrasion grooves are created by the alumina hard asperities, resulting in a two-body abrasive wear mode that leads to surface damage and loss of material. Similar worn scars were found in literature for NiTi specimens against hard materials (WC
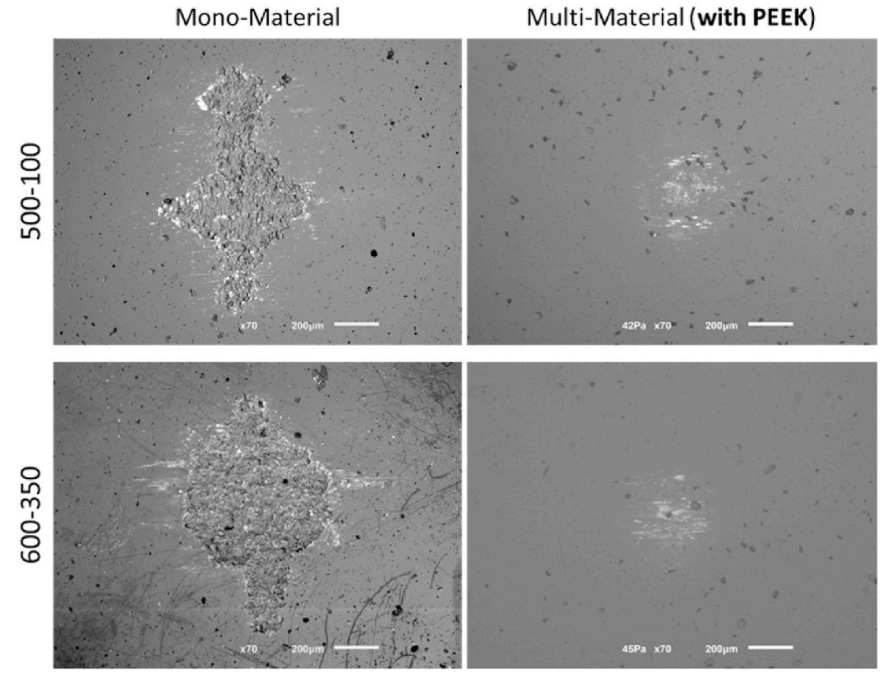

Fig. 10. SEM micrographs of the $\mathrm{Al}_{3} \mathrm{O}_{2}$ balls after wear tests, at lower magnification, for $500-100$ and 600-350 specimens.

and $\mathrm{Si}_{3} \mathrm{~N}_{4}$ balls) [35,53]. Plastic deformation of the wear debris (in lower amounts) and subsequent clustering to form tribolayers are also visible. Also, EDS analysis on the red rectangles drawn on Fig. 7 detected aluminium element on the specimens, meaning that adhesion wear also occur.

Comparing the worn surfaces of mono- and multi-material specimens, it seems that multi-material specimens present smoother wear tracks, with less evident grooves and less wear debris. These smoother scars found on multi-material specimens may be explained by the presence of PEEK, that is protecting the NiTi surface from wear. These results are in accordance with the lower coefficient of friction values found for multi-material specimens, when compared with the monomaterial ones.

SEM micrographs of the worn $\mathrm{Al}_{2} \mathrm{O}_{3}$ balls and corresponding EDS analysis were performed and results are displayed in Figs. 9 and 10 and Table 3 , respectively. 
Table 3

Chemical composition (in wt. \%) of the material transfer zones in $\mathrm{Al} 3 \mathrm{O} 2$ balls.

\begin{tabular}{|c|c|c|c|c|c|c|c|c|c|c|}
\hline \multicolumn{2}{|c|}{ Composition (wt.\%) } & \multirow{2}{*}{$\frac{\mathrm{Ni}}{32.7}$} & \multirow{2}{*}{$\frac{\mathrm{Ti}}{32.0}$} & \multirow{2}{*}{$\frac{\mathrm{Al}}{2.5}$} & & \multirow{2}{*}{$\frac{C}{-}$} & \multirow{2}{*}{$\frac{P}{2.1}$} & \multirow{2}{*}{$\frac{\mathrm{Na}}{-}$} & \multirow{2}{*}{$\frac{\mathrm{Cl}}{-}$} & \multirow{2}{*}{$\begin{array}{l}\text { others } \\
-\end{array}$} \\
\hline 500100 & $\mathrm{Z1}$ & & & & & & & & & \\
\hline 500150 & $\mathrm{Z1}$ & 37.4 & 36.8 & 1.1 & 23.0 & - & 1.6 & - & - & - \\
\hline 500350 & $\mathrm{Z1}$ & 43.5 & 25.3 & 14.3 & 4.6 & 12.3 & - & - & - & - \\
\hline \multirow[t]{2}{*}{$500100 \mathrm{P}$} & $\mathrm{Z1}$ & 20.8 & 20.1 & 19.2 & 33.8 & 4.6 & 1.5 & - & - & - \\
\hline & $\mathrm{Z} 2$ & 17.9 & 9.6 & 31.2 & 35.5 & 4.7 & 1.0 & - & - & - \\
\hline \multirow[t]{3}{*}{$500150 \mathrm{P}$} & $\mathrm{Z1}$ & 20.3 & 13.9 & 20.6 & 34.9 & 8.6 & 1.7 & - & - & - \\
\hline & $\mathrm{Z} 2$ & 5.2 & 6.5 & 20.4 & 49.0 & 7.9 & 6.8 & 2.9 & 0.5 & 0.8 \\
\hline & $\mathrm{Z3}$ & - & - & 22.8 & 37.0 & 36.6 & 1.0 & 1.3 & 1.3 & - \\
\hline \multirow[t]{3}{*}{$500350 \mathrm{P}$} & $\mathrm{Z} 1$ & 24.3 & 22.8 & 17.2 & 28.3 & 6.2 & 1.1 & - & - & - \\
\hline & $\mathrm{Z} 2$ & 20.8 & 3.4 & 17.3 & 38.1 & 15.1 & 0.9 & 3.1 & 1.3 & - \\
\hline & $\mathrm{Z3}$ & 6.8 & 8.5 & 16.9 & 33.4 & 32.2 & 0.9 & 1.4 & - & - \\
\hline 600100 & $\mathrm{Z1}$ & 18.5 & 20.5 & 12.9 & 41.1 & - & 3.6 & 3.0 & - & 0.4 \\
\hline 600150 & $\mathrm{Z1}$ & 38 & 31 & 4.8 & 16.2 & 9.0 & 1.0 & - & - & - \\
\hline 600350 & $\mathrm{Z1}$ & 42.2 & 33.5 & 2.7 & 19.4 & - & 1.4 & 1.0 & - & - \\
\hline \multirow[t]{3}{*}{$600100 \mathrm{P}$} & $\mathrm{Z} 1$ & 19.4 & 16.6 & 21.6 & 34.1 & 6.4 & 0.8 & 1.0 & - & - \\
\hline & $\mathrm{Z} 2$ & 7.3 & 9.3 & 18.5 & 44.9 & 10 & 6.2 & 2.3 & - & 1.5 \\
\hline & $\mathrm{Z3}$ & - & 0.8 & 15.5 & 29.4 & 45.7 & - & 3.2 & 3.7 & 1.6 \\
\hline \multirow[t]{2}{*}{$600150 \mathrm{P}$} & $\mathrm{Z1}$ & 20 & 21.7 & 16.9 & 31.3 & 7.5 & 1.5 & 1.1 & - & - \\
\hline & $\mathrm{Z} 2$ & 11.8 & 11.5 & 18.6 & 41.8 & 7.9 & 5.8 & 2.6 & - & - \\
\hline \multirow[t]{3}{*}{$600350 \mathrm{P}$} & $\mathrm{Z1}$ & 18.9 & 23.7 & 15.9 & 33.2 & 5.4 & 1.7 & 1.2 & - & - \\
\hline & $\mathrm{Z} 2$ & 8.6 & 11.3 & 17.2 & 43.1 & 10.3 & 5.8 & 3.1 & 0.7 & - \\
\hline & $\mathrm{Z3}$ & 2.9 & 2.2 & 14.9 & 33.6 & 40.9 & 0.8 & 2.3 & 2.6 & - \\
\hline
\end{tabular}

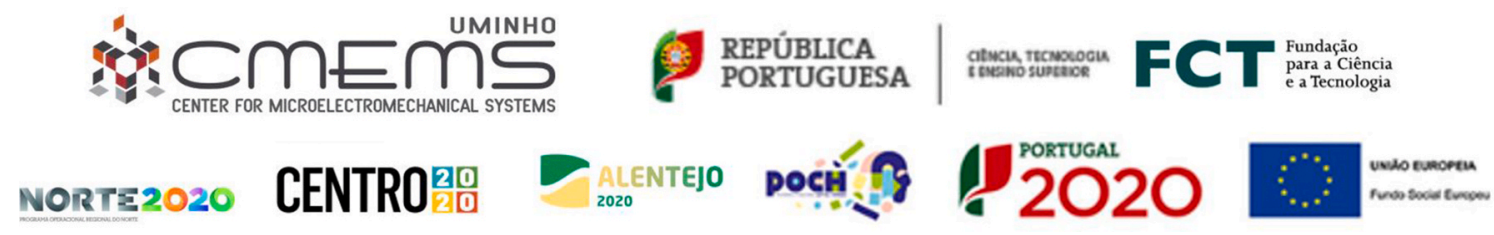

Results from SEM and EDS analyses clearly evidence adhesion wear, once in all $\mathrm{Al}_{2} \mathrm{O}_{3}$ balls $\mathrm{Ni}$ and $\mathrm{Ti}$ elements were detected, proving the metal adherence to the ball surface. Moreover, the micrographs of the balls that slide against to the mono-material specimens shows a much more damaged and fractured surface when compared to the surfaces of the balls corresponding to the multi-material specimens. This phenomenon suggests that in the multi-material specimens, the PEEK seems to reduce the abrasive wear. This can be clearly seen at the SEM images at lower magnifications (Fig. 10), where the mono-material specimens demonstrate a severity in the ball-specimen contact which led to a higher wear of the counterball, when compared with the multi-material.

This phenomenon can be clearly seen in the images at the lowest magnification, where the mono-material samples demonstrate a severity in the contact and consequently, a greater wear of the ball, when compared with the multi-material samples. It is important to note, that this phenomenon is verified in all samples.

Overall, based on these findings, multi-material specimens show a superior wear resistance when compared to the mono-material ones. This means that the proposed solution based on NiTi cellular structures production by SLM, followed by PEEK open-cells filling with Hot Pressing is a promising strategy to improve current implant monomaterial solutions. Additionally, these structures allow to tailor the elastic modulus to values that are within the range of values found for bone.

\section{Conclusions}

In the present study, NiTi mono-material cellular structures were effectively designed and produced by Selective Laser Melting. SEM images, besides proving the effectiveness of the process to produce NiTi cellular structures also demonstrate the effectiveness of the impregnation process to produce multi-material NiTi-PEEK structures. XRD patterns allowed concluding that both mono and multi-material specimens presented austenite as the main phase, with no evidence of other intermetallics. The tribological characterization showed that all the multimaterial NiTi-PEEK structures exhibit a higher wear resistance (lower specific wear rate) and lower COF when compared to the mono-material NiTi structures. These results indicate that the developed solution, i.e., the addition of PEEK to NiTi structures produced by SLM, can provide an improved solution for medical applications when compared with fully metal solutions commercially available.

\section{CRediT authorship contribution statement}

M.M. Costa: Methodology, Investigation, Writing - original draft, Visualization. F. Bartolomeu: Methodology, Writing - review \& editing. J. Palmeiro: Investigation. B. Guimarães: Methodology. N. Alves: Resources. G. Miranda: Conceptualization, Writing - review \& editing, Supervision. F.S. Silva: Conceptualization, Writing - review \& editing, Supervision.

\section{Declaration of competing interest}

The authors declare that they have no known competing financial interests or personal relationships that could have appeared to influence the work reported in this paper.

\section{Acknowledgments}

This work was supported by FCT (Fundação para a Ciência e a 
Tecnologia) through the grant SFRH/BD/140191/2018 and by project NORTE 01-0145_FEDER-000018-HAMaBICo. Additionally, this work is supported by FCT with the reference project UID/EEA/04436/2019.

\section{References}

[1] Li J, Cui X, Hooper GJ, Lim KS, Woodfield TBF. Rational design, biofunctionalization and biological performance of hybrid additive manufactured titanium implants for orthopaedic applications: a review. J. Mech. Behav. Biomed. Mater. 2020;105:103671. https://doi.org/10.1016/j.jmbbm.2020.103671.

[2] Horandghadim N, Khalil-Allafi J, Urgen M. Influence of tantalum pentoxide secondary phase on surface features and mechanical properties of hydroxyapatite coating on NiTi alloy produced by electrophoretic deposition. Surf Coating Technol 2020;386:125458. https://doi.org/10.1016/j.surfcoat.2020.125458.

[3] Zhou D, Gao Y, Lai M, Li H, Yuan B, Zhu M. Fabrication of NiTi shape memory alloys with graded porosity to imitate human long-bone structure. JBE 2015;12: 575-82. https://doi.org/10.1016/S1672-6529(14)60147-5.

[4] Wang Z, Wang C, Li C, Qin Y, Zhong L, Chen B, et al. Analysis of factors influencing bone ingrowth into three-dimensional printed porous metal scaffolds: a review. J Alloys Compd 2017;717:271-85. https://doi.org/10.1016/j. jallcom.2017.05.079.

[5] Bartolomeu F, Costa MM, Gomes JR, Alves N, Abreu CS, Silva FS, et al. Implant surface design for improved implant stability - a study on Ti6Al4V dense and cellular structures produced by Selective Laser Melting. Tribol Int 2019;129: 272-82. https://doi.org/10.1016/j.triboint.2018.08.012.

[6] Costa MM, Bartolomeu F, Alves N, Silva FS, Miranda G. Tribological behavior of bioactive multi-material structures targeting orthopedic applications. J. Mech. Behav. Biomed. Mater. 2019;94:193-200. https://doi.org/10.1016/j. jmbbm.2019.02.028.

[7] Costa MM, Dantas TA, Bartolomeu F, Alves N, Silva FS, Miranda G, et al. Corrosion behaviour of PEEK or $\beta$-TCP-impregnated Ti6Al4V SLM structures targeting biomedical applications. Trans Nonferrous Metals Soc China 2019;29:2523-33. https://doi.org/10.1016/S1003-6326(19)65160-5.

[8] Miranda G, Sousa F, Costa MM, Bartolomeu F, Silva FS, Carvalho O. Surface design using laser technology for Ti6Al4V-hydroxyapatite implants. Optic Laser Technol 2019;109:488-95. https://doi.org/10.1016/j.optlastec.2018.08.034.

[9] Costa MM, Lima R, Melo-Fonseca F, Bartolomeu F, Alves N, Miranda A, et al. Development of $\beta$-TCP-Ti6Al4V structures: driving cellular response by modulating physical and chemical properties. Mater Sci Eng C 2019;98:705-16. https://doi. org/10.1016/j.msec.2019.01.016.

[10] Bartolomeu F, Sampaio M, Carvalho O, Pinto E, Alves N, Gomes JR, et al. Tribological behavior of Ti6Al4V cellular structures produced by Selective Laser Melting. J. Mech. Behav. Biomed. Mater. 2017;69:128-34. https://doi.org/ 10.1016/j.jmbbm.2017.01.004.

[11] Melo-Fonseca F, Lima R, Costa MM, Bartolomeu F, Alves N, Miranda A, et al. 45S5 BAG-Ti6Al4V structures: the influence of the design on some of the physical and chemical interactions that drive cellular response. Mater Des 2018;160:95-105. https://doi.org/10.1016/J.MATDES.2018.08.056.

[12] Ma X, Wang H, Xie H, Qu J, Chen X, Chen F, et al. Engineering the porosity and superelastic behaviors of NiTi alloys prepared by an electro-assisted powder metallurgical route in molten salts. J Alloys Compd 2019;794:455-64. https://doi org/10.1016/j.jallcom.2019.04.166.

[13] Mwangi JW, Nguyen LT, Bui VD, Berger T, Zeidler H, Schubert A. Nitinol manufacturing and micromachining: a review of processes and their suitability in processing medical-grade nitinol. J Manuf Process 2019;38:355-69. https://doi. org/10.1016/j.jmapro.2019.01.003.

[14] Farvizi M, Ebadzadeh T, Vaezi MR, Yoon EY, Kim Y, Kang JY, et al. Effect of starting materials on the wear performance of NiTi-based composites. Wear 2015; 334-335:35-43. https://doi.org/10.1016/j.wear.2015.04.011.

[15] Ao S, Li K, Liu W, Qin X, Wang T, Dai Y, et al. Electrochemical micromachining of NiTi shape memory alloy with ethylene glycol-NaCl electrolyte containing ethanol. J Manuf Process 2020;53:223-8. https://doi.org/10.1016/j.jmapro.2020.02.019.

[16] Shayesteh Moghaddam N, Saghaian SE, Amerinatanzi A, Ibrahim H, Li P, Toker GP, et al. Anisotropic tensile and actuation properties of NiTi fabricated with selective laser melting. Mater Sci Eng A 2018;724:220-30. https://doi.org/10.1016/j. msea.2018.03.072.

[17] Mehrpouya M, Gisario A, Elahinia M. Laser welding of NiTi shape memory alloy: a review. J Manuf Process 2018;31:162-86. https://doi.org/10.1016/j. jmapro.2017.11.011.

[18] Elahinia MH, Hashemi M, Tabesh M, Bhaduri SB. Manufacturing and processing of NiTi implants : a review. Prog Mater Sci 2012;57:911-46. https://doi.org/ 10.1016/j.pmatsci.2011.11.001.

[19] Andani MT, Saedi S, Turabi AS, Karamooz MR, Haberland C, Karaca HE, et al. Mechanical and shape memory properties of porous Ni50.1Ti49.9 alloys manufactured by selective laser melting. J. Mech. Behav. Biomed. Mater. 2017;68: 224-31. https://doi.org/10.1016/j.jmbbm.2017.01.047.

[20] Saedi S, Turabi AS, Andani MT, Haberland C, Elahinia M, Karaca H. Thermomechanical characterization of Ni- rich NiTi fabricated by selective laser melting. Smart Mater Struct 2016;25:35005. https://doi.org/10.1088/0964-1726/ 25/3/035005.

[21] Saedi S, Turabi AS, Andani MT, Haberland C, Karaca H, Elahinia M. The influence of heat treatment on the thermomechanical response of Ni-rich NiTi alloys manufactured by selective laser melting. J Alloys Compd 2016;677:204-10. https://doi.org/10.1016/j.jallcom.2016.03.161.

[22] Haberland C, Elahinia M, Walker JM, Meier H, Frenzel J. On the development of high quality NiTi shape memory and pseudoelastic parts by additive manufacturing. Smart Mater Struct 2014;23:104002. https://doi.org/10.1088 0964-1726/23/10/104002.

[23] Elahinia M, Shayesteh Moghaddam N, Taheri Andani M, Amerinatanzi A, Bimber BA, Hamilton RF. Fabrication of NiTi through additive manufacturing: a review. Prog Mater Sci 2016;83:630-63. https://doi.org/10.1016/j. pmatsci.2016.08.001.

[24] Dufils J, Faverjon F, Héau C, Donnet C, Benayoun S, Valette S. Combination of laser surface texturing and DLC coating on PEEK for enhanced tribological properties. Surf Coating Technol 2017;329:29-41. https://doi.org/10.1016/j surfcoat.2017.09.028.

[25] Sheiko N, Kékicheff P, Marie P, Schmutz M, Jacomine L, Perrin-Schmitt F. PEEK (polyether-ether-ketone)-coated nitinol wire: film stability for biocompatibility applications. Appl Surf Sci 2016;389:651-65. https://doi.org/10.1016/j. apsusc.2016.07.159.

[26] Bartolomeu F, Abreu CS, Moura CG, Costa MM, Alves N, Silva FS, et al. Ti6Al4VPEEK multi-material structures - design, fabrication and tribological characterization focused on orthopedic implants. Tribol Int 2019;131:672-8. https://doi.org/10.1016/j.triboint.2018.11.017.

[27] Bartolomeu F, Buciumeanu M, Costa MM, Alves N, Gasik M, Silva FS, et al. Multimaterial Ti6Al4V \& PEEK cellular structures produced by Selective Laser Melting and Hot Pressing: a tribocorrosion study targeting orthopedic applications. J. Mech. Behav. Biomed. Mater. 2019;89:54-64. https://doi.org/10.1016/j. jmbbm.2018.09.009.

[28] Sampaio M, Buciumeanu M, Henriques B, Silva FS, Souza JCM, Gomes JR. Tribocorrosion behavior of veneering biomedical PEEK to Ti6Al4V structures. J. Mech. Behav. Biomed. Mater. 2016;54:123-30. https://doi.org/10.1016/j. jmbbm.2015.09.010.

[29] Geetha M, Singh AK, Asokamani R, Gogia AK. Ti based biomaterials, the ultimate choice for orthopaedic implants - a review. Prog Mater Sci 2009;54:397-425. https://doi.org/10.1016/j.pmatsci.2008.06.004.

[30] Chen Q, Thouas GA. Metallic implant biomaterials. Mater Sci Eng R 2015;87:1-57. https://doi.org/10.1016/j.mser.2014.10.001.

[31] Holzwarth U, Cotogno G. Total hip arthroplasty - state of the art, challenges and prospects. 2012. https://doi.org/10.2788/31286.

[32] Buciumeanu M, Almeida S, Bartolomeu F, Costa MM, Alves N, Silva FS, et al. Ti6Al4V cellular structures impregnated with biomedical PEEK - new material design for improved tribological behavior. Tribol Int 2018;119:157-64. https:// doi.org/10.1016/j.triboint.2017.10.038.

[33] Levintant-Zayonts N, Starzynski G, Kopec M, Kucharski S. Characterization of NiTi SMA in its unusual behaviour in wear tests. Tribol Int 2019;137:313-23. https:// doi.org/10.1016/j.triboint.2019.05.005.

[34] Neupane R, Farhat Z. Wear and dent resistance of superelastic TiNi alloy. Wear 2013;301:682-7. https://doi.org/10.1016/j.wear.2012.11.017.

[35] Neupane R, Farhat Z. Wear mechanisms of nitinol under reciprocating sliding contact. Wear 2014;315:25-30. https://doi.org/10.1016/j.wear.2014.02.018.

[36] Bartolomeu F, Costa MM, Alves N, Miranda G, Silva FS. Additive manufacturing of NiTi-Ti6Al4V multi-material cellular structures targeting orthopedic implants. Optic Laser Eng 2020;134:106208. https://doi.org/10.1016/j. optlaseng.2020.106208.

[37] Bartolomeu F, Costa MM, Alves N, Miranda G, Silva FS. Engineering the elastic modulus of NiTi cellular structures fabricated by selective laser melting. J. Mech. Behav. Biomed. Mater. 2020;110:103891. https://doi.org/10.1016/j. jmbbm.2020.103891.

[38] Bartolomeu F, Dourado N, Pereira F, Alves N, Miranda G, Silva FS. Additive manufactured porous biomaterials targeting orthopedic implants: a suitable combination of mechanical, physical and topological properties. Mater Sci Eng C 2020;107:110342. https://doi.org/10.1016/j.msec.2019.110342.

[39] Bartolomeu F, Fonseca J, Peixinho N, Alves N, Gasik M, Silva FS, et al. Predicting the output dimensions, porosity and elastic modulus of additive manufactured biomaterial structures targeting orthopedic implants. J. Mech. Behav. Biomed. Mater. 2019;99:104-17. https://doi.org/10.1016/j.jmbbm.2019.07.023.

[40] Weißmann V, Wieding J, Hansmann H, Laufer N, Wolf A, Bader R. Specific yielding of selective laser-melted Ti6Al4V open-porous scaffolds as a function of unit cell design and dimensions. Metals 2016;6(7):116. https://doi.org/10.3390/ met6070166.

[41] Ran Q, Yang W, Hu Y, Shen X, Yu Y, Xiang Y, et al. Osteogenesis of 3D printed porous Ti6Al4V implants with different pore sizes. J. Mech. Behav. Biomed. Mater. 2018;84:1-11. https://doi.org/10.1016/j.jmbbm.2018.04.010.

[42] Arabnejad S, Burnett Johnston R, Pura JA, Singh B, Tanzer M, Pasini D. Highstrength porous biomaterials for bone replacement: a strategy to assess the interplay between cell morphology, mechanical properties, bone ingrowth and manufacturing constraints. Acta Biomater 2016;30:345-56. https://doi.org/ 10.1016/j.actbio.2015.10.048.

[43] Taniguchi N, Fujibayashi S, Takemoto M, Sasaki K, Otsuki B, Nakamura T, et al Effect of pore size on bone ingrowth into porous titanium implants fabricated by additive manufacturing: an in vivo experiment. Mater Sci Eng C 2016;59:690-701. https://doi.org/10.1016/j.msec.2015.10.069.

[44] Miranda G, Faria S, Bartolomeu F, Pinto E, Alves N, Peixinho N, et al. A study on the production of thin-walled Ti6Al4V parts by selective laser melting. J Manuf Process 2019;39:346-55. https://doi.org/10.1016/j.jmapro.2018.12.036. 
[45] Saedi S, Turabi AS, Andani MT, Moghaddam NS, Elahinia M, Karaca HE. Texture, aging, and superelasticity of selective laser melting fabricated Ni-rich NiTi alloys. Mater Sci Eng A 2017;686:1-10. https://doi.org/10.1016/j.msea.2017.01.008.

[46] Li DY. A new type of wear-resistant material: pseudo-elastic TiNi alloy. Wear 1998; 221:116-23. https://doi.org/10.1016/S0043-1648(98)00269-5.

[47] Yan L, Liu Y. Wear behavior of austenitic NiTi shape memory alloy. Shape Memory and Superelasticity 2015;1:58-68. https://doi.org/10.1007/s40830-015-0008-1.

[48] Lin HC, Liao HM, He JL, Chen KC, Lin KM. Wear characteristics of TiNi shape memory alloys. Metall Mater Trans A 1997;28:1871-7. https://doi.org/10.1007/ s11661-997-0117-3.

[49] Tillmann W, Momeni S. Tribological performance of near equiatomic and Ti-rich NiTi shape memory alloy thin films. Acta Mater 2015;92:189-96. https://doi.org/ 10.1016/j.actamat.2015.04.006.
[50] Koike H, Kida K, Santos EC, Rozwadowska J, Kashima Y, Kanemasu K. Selflubrication of PEEK polymer bearings in rolling contact fatigue under radial loads. Tribol Int 2012;49:30-8. https://doi.org/10.1016/j.triboint.2011.12.005.

[51] Bartolomeu F, Buciumeanu M, Pinto E, Alves N, Carvalho O, Silva FS, et al. 316L stainless steel mechanical and tribological behavior - a comparison between selective laser melting, hot pressing and conventional casting. Additive Manufacturing 2017;16:81-9. https://doi.org/10.1016/j.addma.2017.05.007.

[52] Bartolomeu F, Buciumeanu M, Pinto E, Alves N, Silva FS, Carvalho O, et al. Wear behavior of Ti6Al4V biomedical alloys processed by selective laser melting, hot pressing and conventional casting. Trans Nonferrous Metals Soc China 2017;27: 829-38. https://doi.org/10.1016/S1003-6326(17)60060-8.

[53] Zhang F, Zheng L, Wang Y, Zhang $\mathrm{H}$. Effect of Ni content and Hf addition on the unlubricated wear performance of Ni-rich NiTi alloys. Intermetallics 2019;112: 106548. https://doi.org/10.1016/j.intermet.2019.106548. 